\title{
Bactericidal activities of the cationic steroid CSA-I 3 and the cathelicidin peptide LL-37 against Helicobacter pylori in simulated gastric juice
}

Katarzyna Leszczyńska1, Andrzej Namiot², David E Fein ${ }^{3}$, Qi Wen ${ }^{4}$, Zbigniew Namiot ${ }^{5}$, Paul B Savage ${ }^{6}$, Scott Diamond ${ }^{3}$, Paul A Janmey ${ }^{4}$ and Robert Bucki*4

Address: ${ }^{1}$ Department of Diagnostic Microbiology, Medical University of Bialystok, 15-230 Bialystok, Poland, ${ }^{2}$ Department of Anatomy, Medical University of Bialystok, 15-230 Bialystok, Poland, ${ }^{3}$ Penn Center for Molecular Discovery, Institute for Medicine and Engineering, Department of Chemical and Biomolecular Engineering, University of Pennsylvania, Philadelphia, PA 19104, USA, ${ }^{4}$ Department of Physiology and the Institute for Medicine and Engineering, University of Pennsylvania, 1010 Vagelos Research Laboratories, 3340 Smith Walk, Philadelphia, PA, 19104 USA, ${ }^{5}$ Department of Physiology, Medical University of Bialystok, 15-230 Bialystok, Poland and ${ }^{6}$ Department of Chemistry and Biochemistry, Brigham Young University, C-I00 BNSN, Provo, UT 84602, USA

Email: Katarzyna Leszczyńska - katles@onet.eu; Andrzej Namiot - namiota@poczta.onet.pl; David E Fein - dfein@seas.upenn.edu; Qi Wen - wenqi@mail.med.upenn.edu; Zbigniew Namiot - namiotz@poczta.onet.pl; Paul B Savage - paul_savage@byu.edu; Scott Diamond - sld@seas.upenn.edu; Paul A Janmey - janmey@mail.med.upenn.edu; Robert Bucki* - buckirob@mail.med.upenn.edu

* Corresponding author

Published: 3 September 2009

BMC Microbiology 2009, 9:187 doi:10.1/86/147|-2180-9-187
Received: 28 April 2009

Accepted: 3 September 2009

This article is available from: http://www.biomedcentral.com/l47|-2/80/9/187

(C) 2009 Leszczyńska et al; licensee BioMed Central Ltd.

This is an Open Access article distributed under the terms of the Creative Commons Attribution License (http://creativecommons.org/licenses/by/2.0),

which permits unrestricted use, distribution, and reproduction in any medium, provided the original work is properly cited.

\begin{abstract}
Background: The worldwide appearance of drug-resistant strains of $H$. pylori motivates a search for new agents with therapeutic potential against this family of bacteria that colonizes the stomach, and is associated with adenocarcinoma development. This study was designed to assess in vitro the anti-H. pylori potential of cathelicidin LL-37 peptide, which is naturally present in gastric juice, its optimized synthetic analog WLBU2, and the non-peptide antibacterial agent ceragenin CSA-I 3.
\end{abstract}

Results: In agreement with previous studies, increased expression of hCAP-I8/LL-37 was observed in gastric mucosa obtained from $\mathrm{H}$. pylori infected subjects. MBC (minimum bactericidal concentration) values determined in nutrient-containing media range from $100-800 \mu \mathrm{g} / \mathrm{ml}$ for LL37, $17.8-142 \mu \mathrm{g} / \mathrm{ml}$ for WLBU2 and $0.275-8.9 \mu \mathrm{g} / \mathrm{ml}$ for ceragenin CSA-13. These data indicate substantial, but widely differing antibacterial activities against clinical isolates of $H$. pylori. After incubation in simulated gastric juice (low $\mathrm{pH}$ with presence of pepsin) CSA-13, but not LL-37 or WLBU2, retained antibacterial activity. Compared to LL-37 and WLBU2 peptides, CSA-I 3 activity was also more resistant to inhibition by isolated host gastric mucins.

Conclusion: These data indicate that cholic acid-based antimicrobial agents such as CSA-I 3 resist proteolytic degradation and inhibition by mucin and have potential for treatment of $H$. pylori infections, including those caused by the clarithromycin and/or metronidazole-resistant strains. 


\section{Background}

Helicobacter pylori is carried by more than half of the world's adult population [1]. It can chronically colonize the human gastric mucosa, where it is found in the mucus layer and is adhered to epithelial cells [2]. Although most infected subjects remain asymptomatic, infection with $H$. pylori can promote severe gastritis [3] and significantly increase the risk of gastric malignancies $[4,5]$. In some epidemiological studies, $H$. pylori eradication was shown to be effective in gastric cancer prevention [6,7]. Additionally, $H$. pylori eradication was found to decrease the incidence and the severity of lesions with carcinogenic potential in animal models $[8,9]$. Natural mechanisms that protect the host from $H$. pylori infections depend on the function of the innate defense system in which antibacterial peptides such as cathelicidin LL-37 $[10,11]$ and O-glycans in gastric mucin [12] play a key role.

LL-37 is a proteolytically processed peptide derived from the C-terminal domain of human cathelicidin (hCAP-18/ LL-37) that is constitutively released to the extracellular space by phagocytic granulocytes and epithelial cells [13]. Functions ascribed to LL-37 include prevention of bacterial growth [14], neutralization of bacterial wall molecule bioactivity [15], and activation of host cells by binding specific cell membrane receptors [16-18]. H. pylori upregulates the production of LL-37/hCAP18 by the gastric epithelium, suggesting that cathelicidin or its derivative LL37 contributes to determining the balance between host mucosal defense and $H$. pylori survival mechanisms that govern chronic infection with this gastric pathogen $[10,11]$.

Cationic antibacterial peptides (CAPs) including LL-37 have been extensively investigated as a potential source of new antibacterial molecules. The engineered WLBU2 peptide whose residues are arranged to form an amphipathic helical structure with optimal charge and hydrophobic density, overcomes some limitations of natural LL-37 such as sensitivity to $\mathrm{Mg}^{2+}$ or $\mathrm{Ca}^{2+}$ and inactivation by blood serum [19]. Therefore WLBU2 could treat infections where LL-37 is ineffective. In order to generate molecules able to mimic CAPs' ability to compromise bacterial membrane integrity, non-peptide ceragenins with cationic, facially amphiphilic structures characteristic of most antimicrobial peptides were developed. Ceragenins such as CSA-13 reproduce the required CAP morphology using a bile-acid scaffolding and appended amine groups [20]. They are bactericidal against both Gram-positive and Gram-negative organisms, including drug-resistant bacteria such as clinically relevant methicillin-resistant Staphylococcus aureus (MRSA), and a previous susceptibility study demonstrated that CSA-13 has a $\mathrm{MIC}_{50} / \mathrm{MBC}_{50}$ ratio of $1[21,22]$. In this study we compare the bactericidal potency of LL-37, WLBU2 and CSA-13 against clinical isolates of $H$. pylori. The results suggest that cholic acid-based mimics of antimicrobial peptide such as CSA-13 have potential for treatment of H. pylori infection, including those caused by the clarithromycin and/or metronidazole-resistant strains.

\section{Results \\ Immunohistochemical probing of human gastric mucosa sections with anti-hCAP-I8/LL-37 antibody}

Microscopic images of mucosal biopsies after immunohistochemical evaluation with anti-hCAP-18/LL-37 antibody are shown in Figure 1. The DAB-positive staining indicates the presence of the LL-37 peptide and/or its parent protein hCAP-18. High intensity DAB staining (indicated by brown color) at the mucus-producing epithelial cells and fundic glands indicates high accumulation of hCAP-18/LL-37 peptide most likely driven by LL-37 specific interaction with mucin, which was reported in previous studies $[23,24]$. The distribution of hCAP-18/LL-37 in the more differentiated epithelial cell population of the gastric mucosa differs from that found for human $\beta$ defensin $2[10]$ or lysozyme [25] but is similar to that observed in the colon [26]. Gastric mucosal biopsies from patients infected with $H$. pylori show higher intensity of DAB staining compared to those obtained from noninfected subjects. According to previous reports, this result indicates a host defense response to $H$. pylori [11], which is partly based on increased expression of hCAP-18/LL-37 by gastric epithelial cells.

\section{Bactericidal activity of LL-37, WLBU-2 peptides and ceragenin CSA- 13 against different strains of $\mathrm{H}$. pylori}

To identify resistant strains, clinical isolates of $H$. pylori were subjected to MIC evaluation (Table 1) with several antibiotics currently used in clinical treatment of $H$. pylori infection. Among seven tested isolates obtained from different subjects, strain 4 was resistant to metronidazole and strains 5, 6, 7 were resistant to both metronidazole and clarithromycin. All isolates were susceptible to amoxicillin and tetracycline. Consistent with previous reports on the effects of hBD-1, h-BD-2 and LL-37 peptides against $H$. pylori $[10,11]$ all isolated strains of $H$. pylori were killed after 6 hours incubation with LL-37, WLBU2 and CSA-13 with average $\mathrm{MBC}(\mu \mathrm{g} / \mathrm{ml})$ values $8.9 \pm 4.03$; $5.23 \pm 2.7$ and $0.31 \pm 0.25$ when MBC was evaluated in HEPES buffer, or $300 \pm 232,53 \pm 41$ and $2.98 \pm 3.11$ when $\mathrm{MBC}$ was evaluated in Brucella Broth Bullion respectively (Figure 2). Evaluation of MBC values in HEPES buffer with addition of $2 \mathrm{mM} \mathrm{MgCl}_{2}$ for $H$. pylori ATCC 43504 revealed an eight fold increase for LL-37, and a four fold increase for both WLBU2 and CSA-13 (data not show).

\section{Antibacterial activity of LL-37, WLBU2 and CSA-I3 after pre-incubation at low $\mathrm{pH}$ with pepsin or mucin}

In addition to known inhibition of CAPs antibacterial activity by divalent cations such as $\mathrm{Mg}^{2+}$ and $\mathrm{Ca}^{2+}$, the proteolytic activity of pepsin may also compromise CAPs 

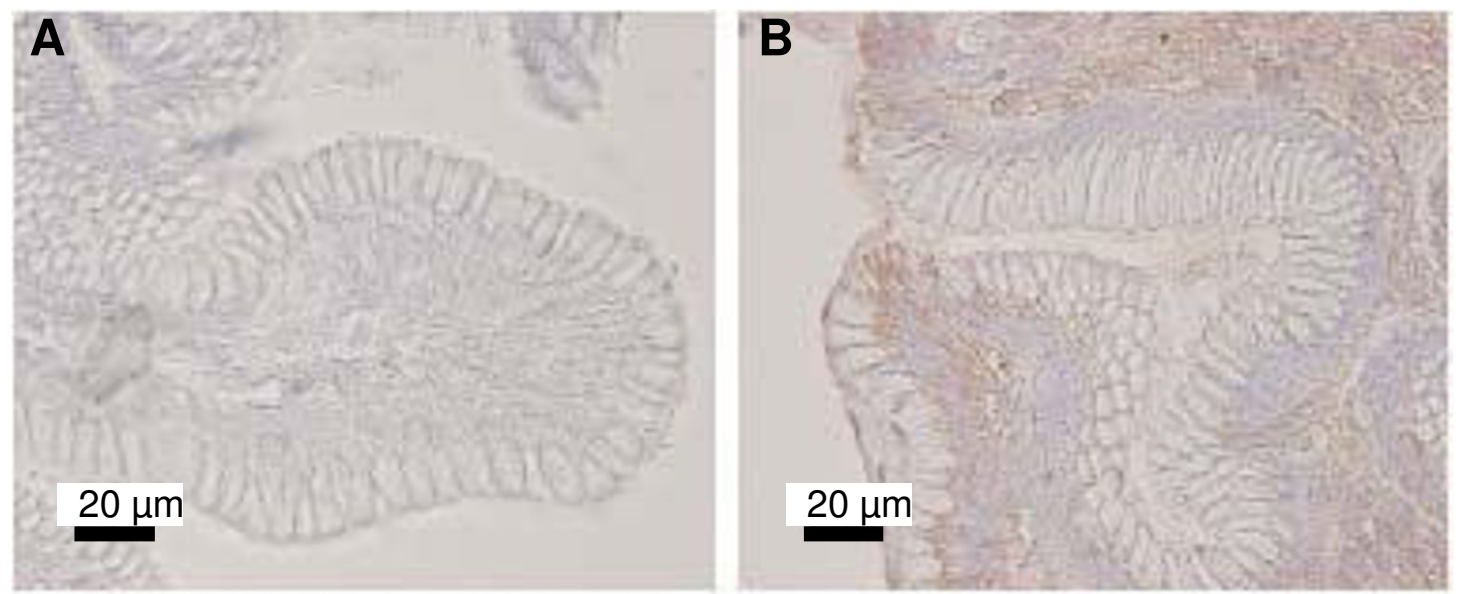

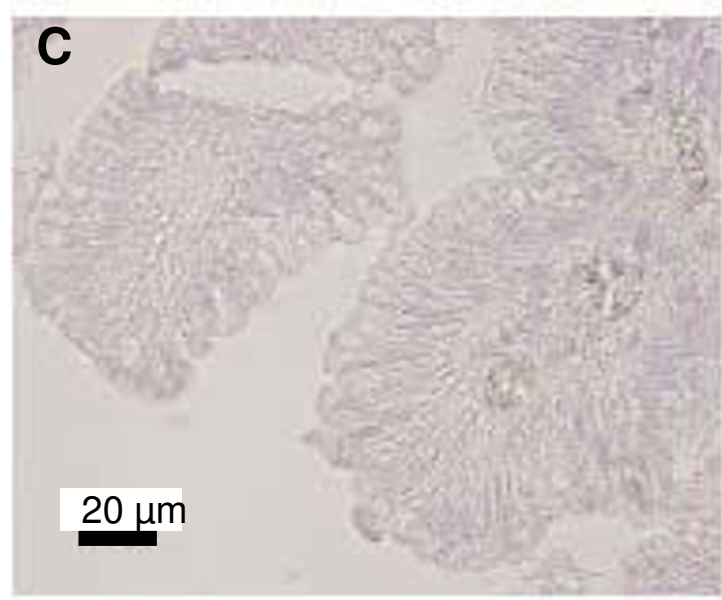

Haematoxylin

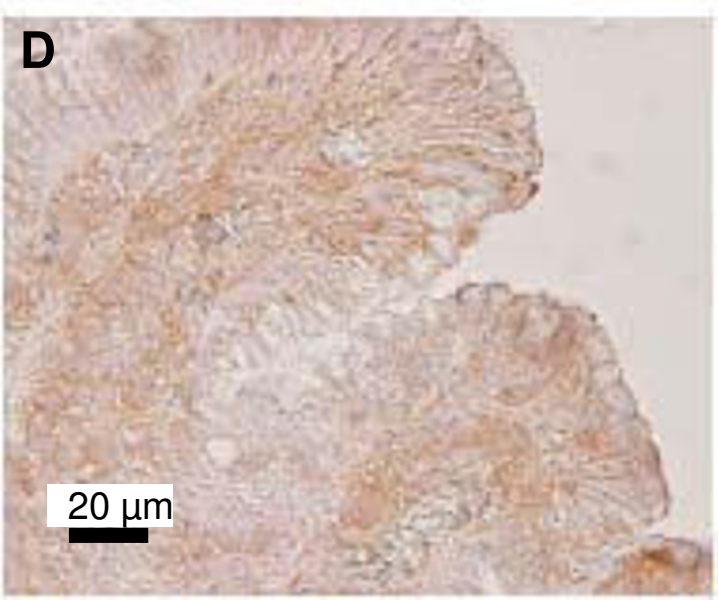

Anti-hCAP-18/LL-37

\section{Figure I}

Presence of hCAP- I 8/LL-37 peptide in mucosal biopsies from the human stomach detected using immunohistochemical analysis with monoclonal antibodies to human CAP- I 8/LL-37. Samples A/B and C/D represent the specimens obtained from non-infected and $H$. pylori infected subjects respectively. Data shown are representative of five experiments.

function in the gastric juice environment with the presence of mucins, and low $\mathrm{pH}$. To address this possibility we evaluated the antibacterial activity against Escherichia coli MG1655 after 3 hours pre-incubation of LL-37, WLBU2 and CSA-13 in simulated gastric juice in comparison to activity after their pre-incubation in PBS at pH 7.4. Before conducting the killing assay, the $\mathrm{pH}$ of samples with low $\mathrm{pH}$ and low $\mathrm{pH} / \mathrm{pepsin}$ was adjusted to 7.4. The antibacterial activity of LL-37 and WLBU2 peptides against $E$. coli MG1655 was not significantly changed after pre-incubation at $\mathrm{pH} \sim 1.5$, but was lost after pre-incubation at $\mathrm{pH}$ $\sim 1.5$ in the presence of pepsin (Figure 3A and 3B). In contrast, the antibacterial activity of CSA-13 was unchanged by pre-incubation at $\mathrm{pH} \sim 1.5$ with or without pepsin (Figure $3 \mathrm{C}$ ). On the other hand, bactericidal activities of all components were compromised to various extents when tested using a bacterial killing assay in the presence of purified gastric mucin. In close agreement with results obtained from this E. coli MG1655 study, MBC values of LL-37 peptide evaluated after $1 \mathrm{H}$ pre-incubation with buffer at low $\mathrm{pH}$ containing pepsin or mucin was increased but those of CSA-13 were nearly unchanged (Figure 3D). All evaluated agents lost antibacterial activity in PBS supplemented with 10\% human bile (a concentration that does not interfere with E. coli MG1655 growth data not shown). This result suggests that physico-chemical properties of antibacterial molecules promote their insertion in bile lipoprotein, thereby limiting their interaction with the bacterial wall. There has been no study to evaluate antibacterial activity of CAPs in duodenal juice, but these results indicate that bile reflux into the stomach may interfere with CAPs activity. 
A

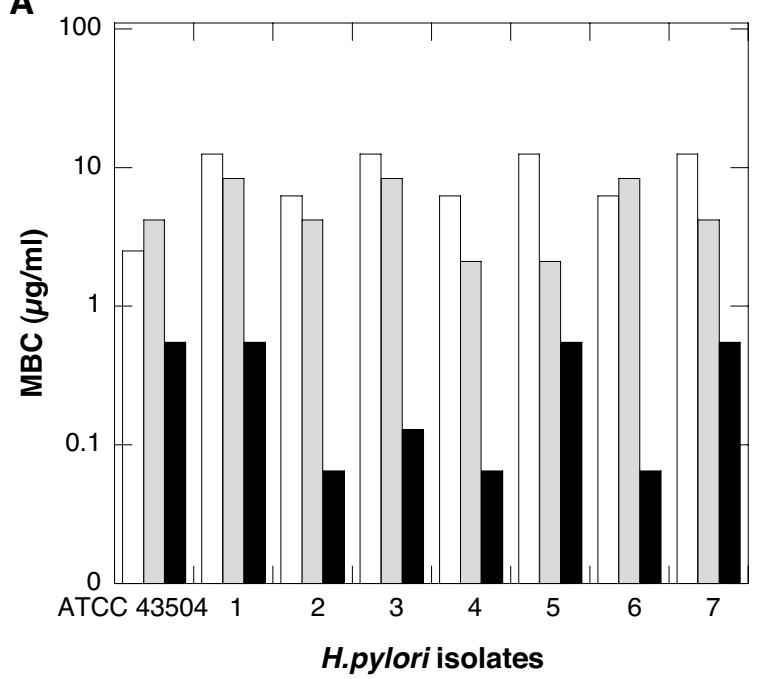

B

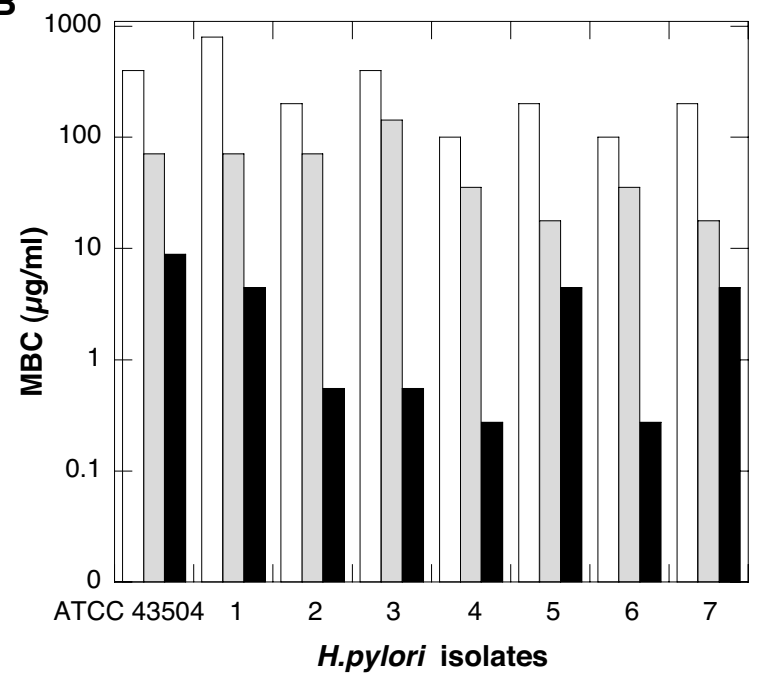

Figure 2

Bactericidal activity against $\boldsymbol{H}$. pylori. Minimum bactericidal concentration (MBC) of LL-37 (white column), WLBU2 (gray column) and CSA-13 (black column) against $H$. pylori (ATCC 43504 strain and seven clinical isolates obtained from mucosal samples from different subjects) evaluated in HEPES (panel A) or Brucella Broth Bulion (panel B). MBC indicates concentrations at which compounds completely eradicate an inoculum of $H$. pylori.

\section{Analytical characterization of LL-37 and CSA-13 after incubation with pepsin}

Mass spectrometry analysis (Figure 4) reveals that three hours incubation with pepsin results in extensive degradation of LL-37. However, at low $\mathrm{pH}$, pepsin digestion is highly specific and LL-37 peptide cleavage is limited to the site with hydrophobic amino acids. Potential cleavage sites predicted by PeptideCutter characterization software http://kr.expasy.org/tools/peptidecutter/, suggest that LL37 digestion with pepsin in our experimental conditions
Table I: Evaluation of sensitivity of clinical strains of $H$. pylori to antibiotics.

\begin{tabular}{ccccc}
\hline H. pylori strains & \multicolumn{4}{c}{ Antibiotics } \\
\cline { 2 - 5 } & AMX & CLR & TET & Metronidazole \\
ATCC 43504 & 0.016 & 0.094 & 0.25 & $64.0{ }^{\circledR}$ \\
I & 0.094 & 0.125 & 0.75 & 0.19 \\
2 & $<0.016$ & 0.19 & 0.125 & 0.094 \\
3 & 0.016 & 0.25 & 3.0 & 0.5 \\
4 & 0.032 & 0.047 & 2.0 & $32.0^{\circledR}$ \\
5 & 0.25 & $64.0{ }^{\circledR}$ & 1.0 & $96.0{ }^{\circledR}$ \\
6 & 0.032 & $1.5{ }^{\circledR}$ & 1.5 & $32.0{ }^{\circledR}$ \\
7 & 0.047 & $1.5{ }^{\circledR}$ & 2.0 & $48.0{ }^{\circledR}$ \\
\hline
\end{tabular}

MIC values $(\mu \mathrm{g} / \mathrm{ml})(\mathrm{AMX}$-amoxicillin, CLR-clarithromycin, TETtetracycline)

should release 11 products, including 3 shorter peptides (RKSKEKIGKE, FKRIVQRIKD and LVPRTES). These predictions are consistent with mass spectral analysis, which does not show the presence of any intact LL-37 remaining following incubation with pepsin at low $\mathrm{pH}$, but does reveal the emergence of multiple new peaks with different retention times. The remaining antibacterial activity of LL37 following treatment with pepsin (Figure 3A and 3D) in the killing assays likely represents the residual activity of these LL-37 fragments. Contrary to the observed degradation of LL-37, CSA-13 analytical characterization was not changed after incubation with pepsin at low $\mathrm{pH}$.

\section{Toxicity of LL-37, WLBU2 and CSA- 13 against RBC and human adenocarcinoma cells}

Non-specific insertion of antibacterial peptides and their mimics into host cell membranes can cause toxicity. Host cell membrane permeabilization can be measured by the release of proteins such as hemoglobin and LDH from the cytosol to the extracellular space. By evaluating hemoglobin and LDH release (Figure 5A and 5B), we show no significant membrane permeabilization by any tested molecules in the range at which they have bactericidal activity in saline buffers (Figure 2A, Figure 3). This finding was confirmed by microscopic evaluation of adenocarcinoma cell morphology showing no visible difference between the control cells and those treated with $10 \mu \mathrm{g} / \mathrm{ml}$ LL-37, WLBU2 or CSA-13 (Figure 5C). However an increase in hemoglobin and LDH release was observed with increasing concentration. Among the three molecules tested, WLBU2 was the strongest hemolytic agent, but all of them showed similar ability to compromise adenocarcinoma cell membrane integrity (Figure 5B and 5C). CSA-13 bactericidal concentrations against $H$. pylori and E. coli MG1655 (Figures 2A, 2B and 3C) evaluated in saline as well as nutrient containing buffer were below its minimal hemolytic concentration and below concentrations causing dysfunction of adenocarcinoma cell membranes. 
A
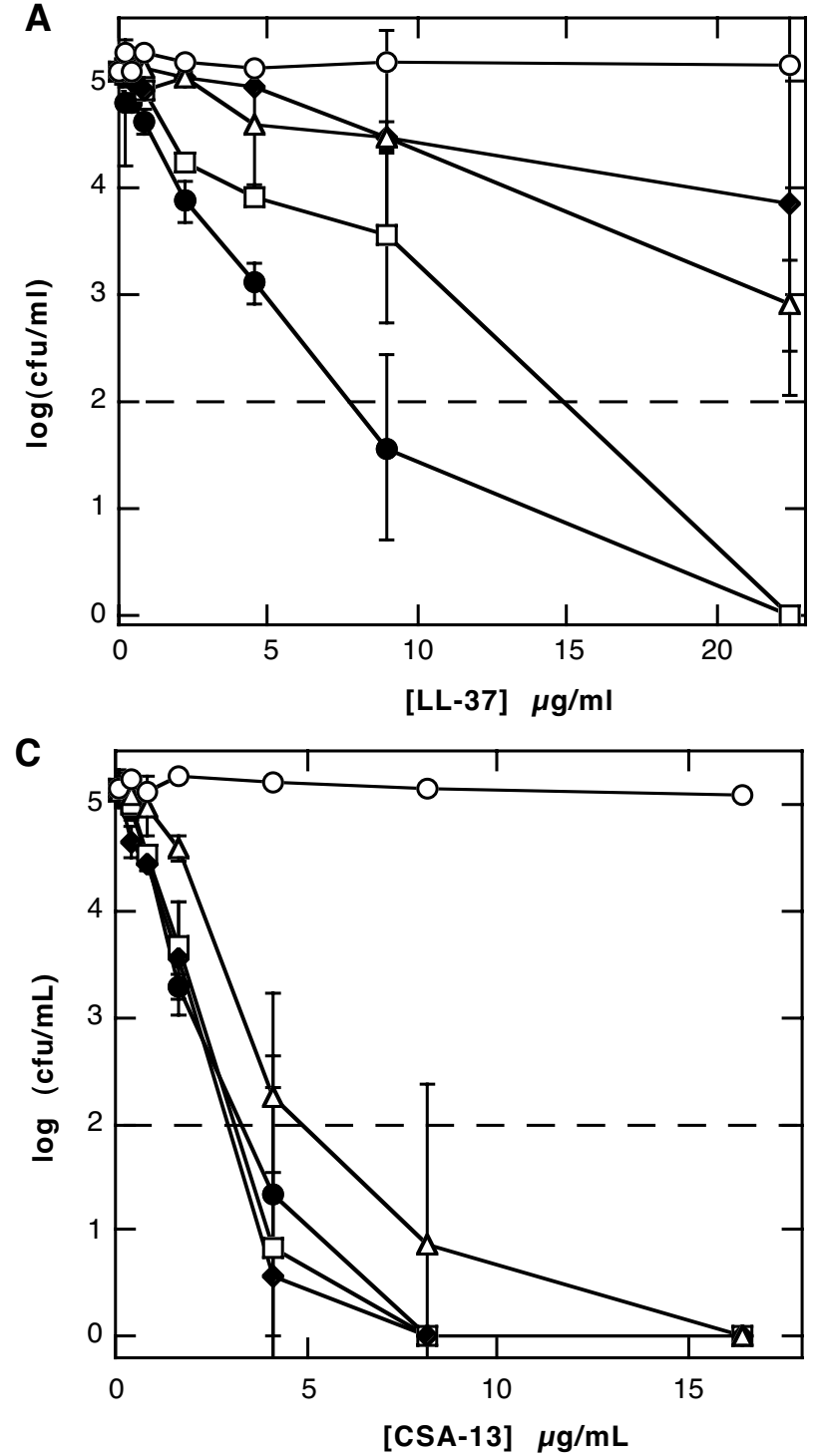

B

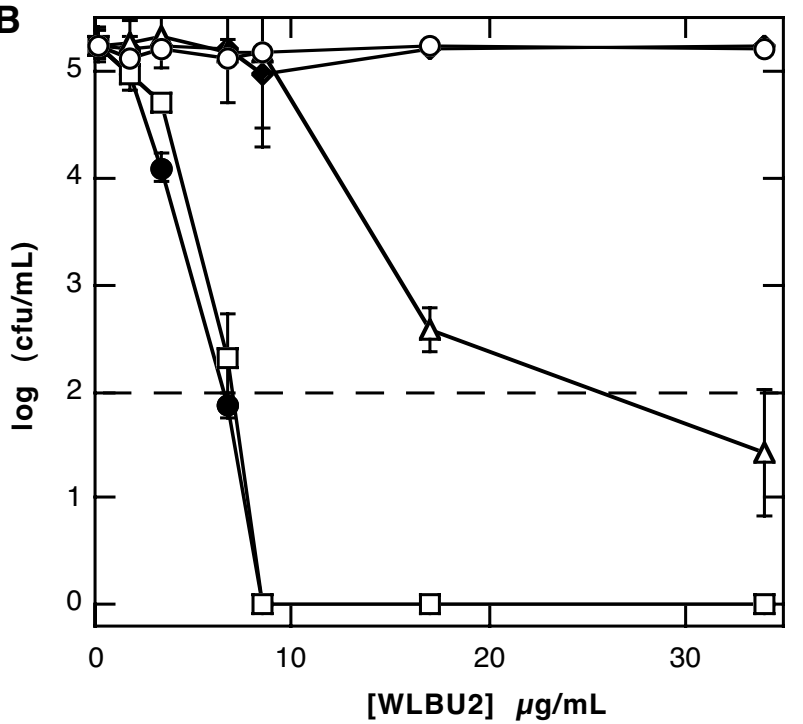

D 1000

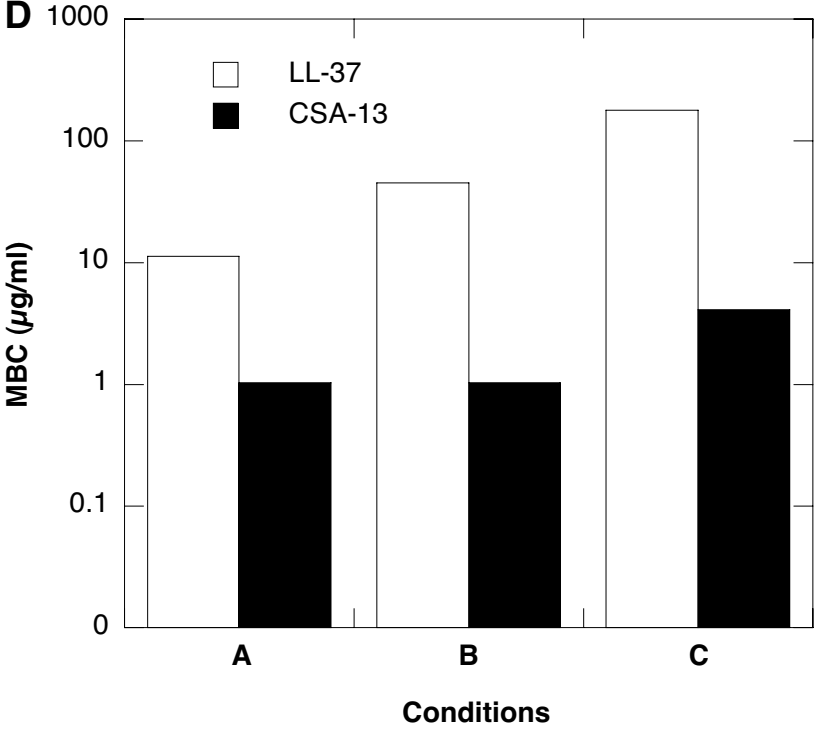

Figure 3

Antibacterial activity against E. coli MG 655 and $H$. pylori strain ATCC 43504 . Antibacterial activity of LL-37 (panel A), WLBU2 (panel B) and CSA-I3 (panel C) against E. coli MGI655 after pre-incubation ( $3 \mathrm{~h}$ at $37^{\circ} \mathrm{C}$ ) in PBS (open circles), simulated gastric juice at $\mathrm{pH} \sim 1.5$ (squares), simulated gastric juice with pepsin (diamonds), simulated gastric juice with mucin (triangles) and PBS with human bile (10\%) obtained from the gallbladder (filled circle). Data shown are means \pm SD of three to four experiments. MBC of LL-37 (white column) and CSA-I 3 (black column) (panel D) against H. pylori (ATCC 43504) after pre-incubation $\left(\mathrm{I} \mathrm{h}\right.$ at $\left.37^{\circ} \mathrm{C}\right)$ in simulated gastric juice at $\mathrm{pH} \sim \mathrm{I} .5(\mathrm{~A})$, simulated gastric juice with pepsin $(\mathrm{B})$ and in presence of mucin (C)

\section{Discussion}

The rate of successful treatment of $H$. pylori stomach infection, achieved with combination therapies of two antibiotics and a proton pump inhibitor has declined from over $90 \%$ to about $80 \%$ during the past decade [27]. In addition, the cost of this therapy is significant, and therefore a need for more widely available means of treating or pre- venting $H$. pylori infection still exists [28]. New agents to treat $H$. pylori infections are necessary also due to increasing drug-resistance problems caused by extensive use of antibiotics [29] and the adaptive survival mechanisms of pathogenic bacteria to counteract currently used antimicrobials. For example, H. pylori strains resistant to amoxicillin, metronidazole and clarithromycin have been 

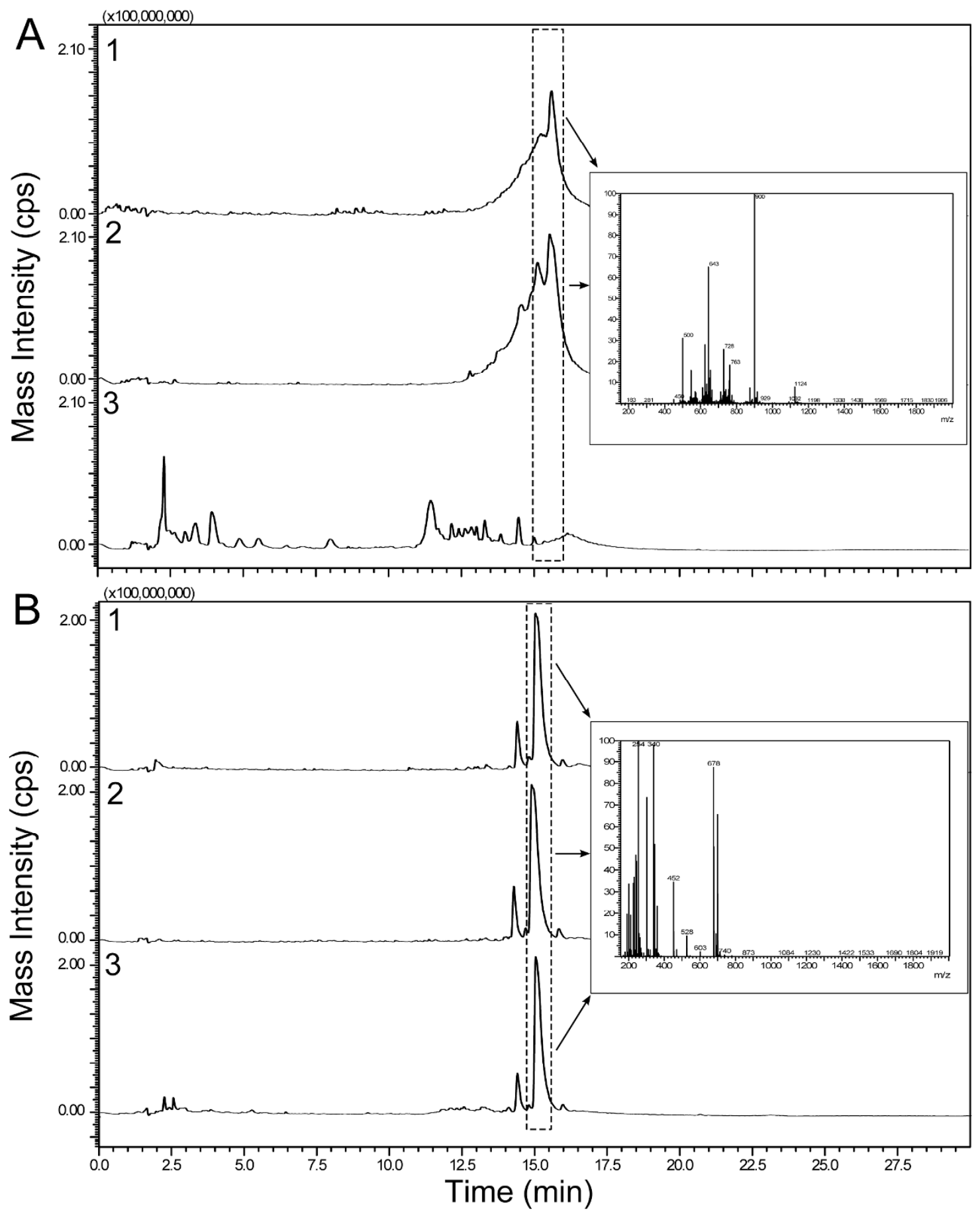

Figure 4

Mass spectrometry analysis. Mass spectrometry analysis of LL-37 (panel A) and CSA-I 3 (panel B) in PBS (curve I) low pH buffer (curve 2) and low $\mathrm{pH}$ buffer with presence of pepsin (curve 3). The total ion chromatogram (TIC) is presented for each sample condition with an inset mass-to-charge $(\mathrm{m} / \mathrm{z})$ spectra showing intensity for the boxed TIC peaks. The molecular weight of intact LL-37 is 4494, which can be observed with multiple charges (m/z $=4 \mathrm{MW}=1 \mathrm{I} 24, \mathrm{~m} / \mathrm{z}=5 \mathrm{MW}=900$, etc) in positive ion mode. The molecular weight of CSAI 3 is 678 , which can be observed directly and with multiple charges. Data from one experiment are shown. 
A

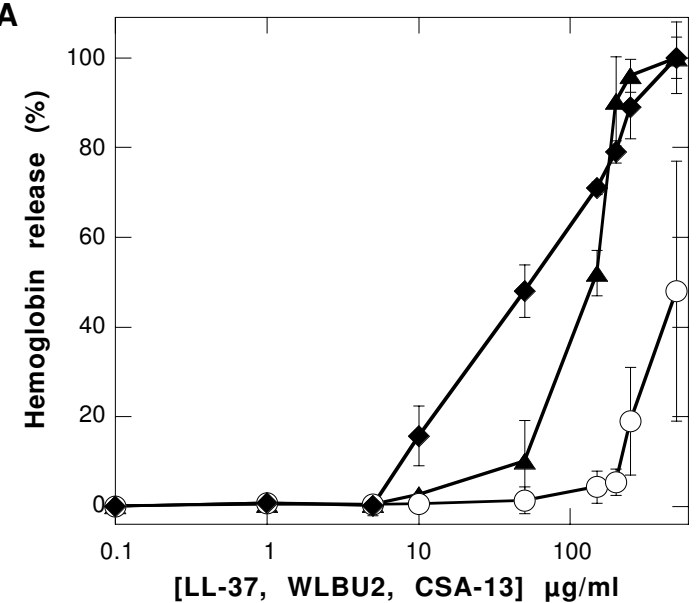

B

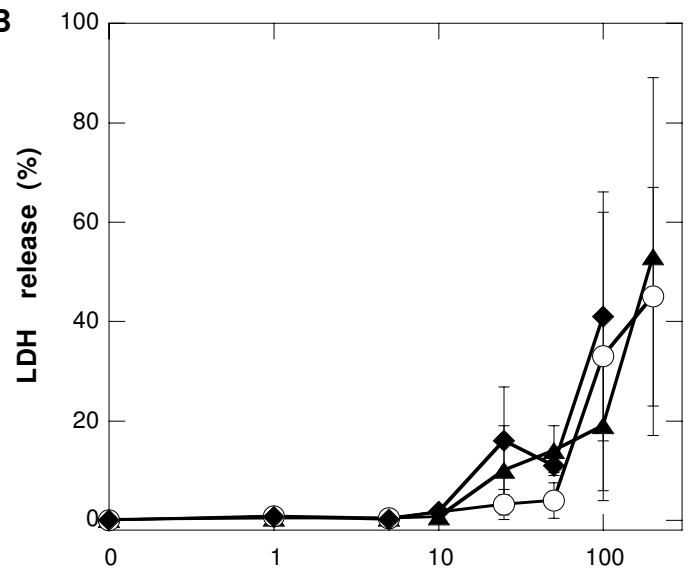

C

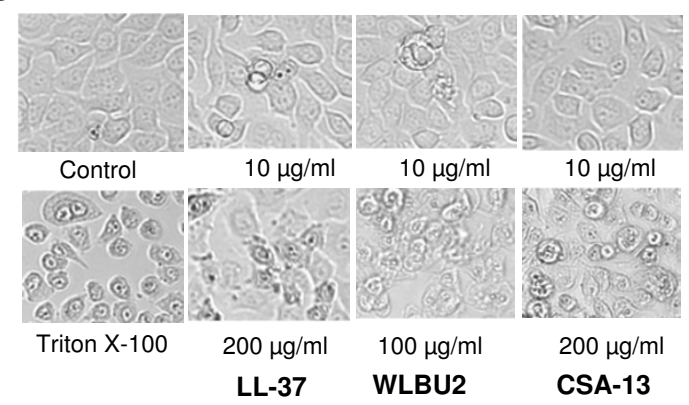

\section{Figure 5}

Evaluation of cell toxicity. Hemoglobin and LDH release from human red blood cells and human gastric adenocarcinoma cells (panel $A$ and $B$ respectively) after addition of LL37 (circles), WLBU2 (diamonds), and CSA-I 3 (triangles), followed by incubation for $\mathrm{I} h$ at $37^{\circ} \mathrm{C}$. Data shown are means $\pm \mathrm{SD}$ of three experiments. Morphology of human gastric adenocarcinoma cells before (control) and after LL-37, WLBU2 and CSA- 13 treatment was evaluated by phase-contrast microscopy (panel C). Data from one representative experiment are shown. Two other experiments revealed similar results. reported [30,31]. Methods to improve treatments for $H$. pylori might be guided by insight into the natural mechanisms by which infected patients respond to this bacterium and the reasons why the normal host-defense mechanisms fail.

This study confirms a previous report of increased hCAP18/LL-37 expression in gastric mucosa of subjects infected with $H$. pylori [11]. This finding suggests that increasing production of the bactericidal peptide LL-37 may play a key role in host defense against H. pylori [11]. However, this bactericidal response in some subjects is insufficient and $H$. pylori infection can still reach a chronic stage. The lack of bactericidal function of LL-37 in this setting has suggested that increased expression of hCAP-18/LL-37 peptide in gastric mucus of infected subjects may have additional functions as an anti-inflammatory and growth stimulating agent. Indeed, it was recently shown that gastric ulcer healing in rats is promoted by cathelicidin-mediated transactivation of epidermal growth factor receptors (EGFR) via the transforming growth factor alpha (TGFo) signaling pathway [32]. Alternatively, loss of defense against $H$. pylori may be due to loss of antibacterial function of LL-37 in the milieu of the gastric mucosa. Consequently, design of antimicrobial agents that are more effective in this setting can be beneficial.

Motivated by immunohistological results, the activity of LL-37 against clinical isolates of $H$. pylori and E. coli MG1655 under biologically relevant conditions was compared with that of the synthetic peptide WLBU2 and the ceragenin CSA-13. This study shows that CSA-13, contrary to LL-37 and WLBU2 peptides, maintains strong bactericidal activity in the presence of mucin and after preincubation with pepsin at low $\mathrm{pH}$. These conditions represent unique challenges related to $H$. pylori treatment, as these bacteria in the stomach are protected from the acidic environment by a thick mucus layer and the effectiveness of many antimicrobial drugs is greatly diminished at acidic $\mathrm{pH}$ [31]. Accordingly, the first effective therapy for $H$. pylori infection was a combination of relatively $\mathrm{pH}$-insensitive antimicrobial drugs such as bismuth, tetracycline and metronidazole [33]. In addition, as the stomach periodically empties its contents (topical therapy tends to be diluted and washed out) the finding that CSA-13 has bactericidal activity at much lower concentration then LL-37, after the same incubation time (3-6 hours) [11], suggests that CSA-13 may have therapeutic potential for treatment of $H$. pylori infection. The antibacterial activity of CSA-13, which has a smaller net charge and a unique distribution of this charge over a steroid scaffold when compared with LL-37 and WLBU2 peptides, was also found to be less inhibited by mucin isolated from gastric mucosa. Thera- 
peutic potential based on the ability of CSA-13 to eradicate $H$. pylori is also supported by previously reported antibacterial activity against other bacteria strains, including clinical isolates of Pseudomonas aeruginosa [21] and $S$. aureus [22]. CSA-13's unique ability to compromise bacterial membrane integrity and the chemical nature of this low-molecular-mass compound that translates to lower cost of synthesis compared to cationic antibacterial peptides suggest that CSA-13 or perhaps other ceragenins have potential for treatment of $H$. pylori infection, including those caused by its resistant strains.

\section{Conclusion}

Bactericidal activity of ceragenin CSA-13 is maintained after preincubation in simulated gastric juice and in the presence of mucin. This in vitro evaluation indicates a significant potential of this molecule in treatment of stomach mucosal infection.

\section{Methods}

\section{Antibacterial agents}

LL-37 ( $\mathrm{NH}_{2}$-LLGDFFRKSKEKIGKEFKRIVQRIKDFLRNLVPRTES-COOH) and WLBU2 $\left(\mathrm{NH}_{2}\right.$-RRWVRRVRRWVRRVVRVVRRWVRR-COOH) peptides were purchased from Bachem (King of Prussia, PA). CSA-13 was prepared as previously described [34]. Amoxicillin (AMX), clarithromycin (CLR), tetracycline (TET) and metronidazole were purchased from Sigma.

\section{Collection of gastric mucosal and bile samples}

During gastroscopy, performed with either a GIF V2 or Q145 (Olympus) gastroscope, several gastric mucosal slices were taken from the prepyloric and corpus regions of the stomach. $H$. pylori infection was established in the biopsy specimens using a urease test (CLO-test). Human bile was obtained from the gallbladder of patients undergoing cholecystectomy. Samples were filter-sterilized through a $0.45 \mu \mathrm{m}$ membrane before being diluted in PBS $(1: 1)$ and mixed with antibacterial agents used in bacteria killing assays. The studies were approved by Medical University of Bialystok Ethics Committee for Research on Humans and Animals, and all patients gave informed written consent for participation in the study.

\section{Immunohistochemical studies}

Immunohistochemical studies were performed on formalin-fixed, paraffin-embedded human gastric mucosal sections using a rabbit anti-LL-37 antibody (H-075-06, used at 1:100 dilution; Phoenix Pharamceuticals Inc.). Paraffin-embedded materials were sectioned to $5 \mu \mathrm{m}$ thickness and floated on distilled water at $45^{\circ} \mathrm{C}$. Sections were then mounted on slides and placed in $57^{\circ} \mathrm{C}$ oven overnight. The sections were deparaffinized according to standard procedures and quenched with $0.9 \%$ hydrogen peroxide in methanol for 30 minutes. The sections were incubated with primary antibody at $37^{\circ} \mathrm{C}$ for 60 minutes, washed with $1 \%$ PBSA (1\% BSA in PBS), and subjected to binding with secondary antibody (biotinylated goat anti-Rabbit IgG, 1:400 dilution). Amplification was performed with a Vectastain ABC kit, and an HRP detection system was used to colocalize peroxidase activity with a DAB substrate. The sections were counterstained with hematoxylin. Samples were viewed with a Nikon Eclipse 80 microscope under $40 \times$ magnification.

\section{Evaluation of MIC and MBC}

The minimal inhibitory concentration (MIC) of conventional antibiotics against seven different clinical isolates of $\mathrm{H}$. pylori $\left(9 \times 10^{8} \mathrm{CFU} / \mathrm{ml}\right)$ was determined using Muller-Hinton agar $(\mathrm{MH})$ containing $5 \%$ sheep blood. The incubation was continued for 4 days at $35^{\circ} \mathrm{C}$ in microaerophilic conditions maintained with use of a Gas Pack-Campylobacter gas generating kit BR60. Clinical isolates of $H$. pylori were considered resistant to respective antibiotics when the MIC values were above $4 \mu \mathrm{g} / \mathrm{ml}$ for AMX, $1 \mu \mathrm{g} / \mathrm{ml}$ for CLR and $16 \mu \mathrm{g} / \mathrm{ml}$ for TET and Metronidazole. The minimal bactericidal concentration (MBC) of antibacterial agents was evaluated using an inoculum at $10^{8} \mathrm{CFU} / \mathrm{ml}$. After a 6-hour incubation at $37^{\circ} \mathrm{C}, 10 \mu \mathrm{l}$ aliquots of the suspensions were spotted on Columbia agar supplemented with sheep blood (5\%).

\section{Bacteria killing assay}

The bactericidal activities of LL-37, WLBU2 peptides and ceragenin CSA-13 against E. coli MG1655 in the presence of mucin or pepsin from porcine mucus (Sigma) and human bile were measured as previously described [35]. Bacteria were grown to mid-log phase at $37^{\circ} \mathrm{C}$ (controlled by the evaluation of optical density at $600 \mathrm{~nm}$ ) and resuspended in PBS buffer $(\mathrm{pH}=7.4)$. The bacteria suspensions were then diluted 10 times in $100 \mu \mathrm{l}$ of solutions containing antibacterial agents by themselves or with mucin $(1000 \mu \mathrm{g} / \mathrm{ml})$, or bile (the final 1:10 bile dilution mimics the environment of the upper small intestine into which bile is secreted [36] $(\mathrm{pH}=7.4))$. In another set of experiments antibacterial activity of these components was determined following their preincubation in simulated gastric juice $[36,37]$ at $\mathrm{pH} \sim 1.5$ with and without pepsin $(0.5 \mathrm{mg} / \mathrm{ml})$. After incubating bacteria with antibacterial molecules for one-hour at $37^{\circ} \mathrm{C}$, the bacterial suspensions were placed on ice and diluted 10- to 1000-fold. Aliquots of each dilution $(10 \mu \mathrm{l})$ were spotted on LB Agar plates for overnight culture at $37^{\circ} \mathrm{C}$. The number of colonies at each dilution was counted the following morning. The colony forming units $(\mathrm{CFU} / \mathrm{ml})$ of the individual samples were determined from the dilution factor.

\section{Mass spectrometry}

Analytical characterization was performed on the CSA-13 and LL-37 suspensions after $3 \mathrm{H}$ incubation with pepsin $(0.5 \mathrm{mg} / \mathrm{ml})$ at low $\mathrm{pH}(\sim 1,5)$ at $37^{\circ} \mathrm{C}$, using the Shimadzu (Columbia, MD) instrument (the LC-MS system 
consisted of a LC-20AB solvent delivery system and SIL20A auto-sampler coupled to dual wavelength UV-Vis detector and a LCMS 2010EV single quadrupole mass spectrometer), coupled to a Shimadzu Premier C18 column $(150 \mathrm{~mm} \times 4.6 \mathrm{~mm}$ i.d., $5 \mu \mathrm{m}$ particle size $)$. The mobile phase flow rate was $1 \mathrm{ml} / \mathrm{min}$ with a starting ratio of $90 \%$ mobile phase A (water) and $10 \%$ mobile phase B (acetonitrile) both with $0.1 \%(\mathrm{v} / \mathrm{v})$ formic acid. The analytical method consisted of the following steps: (i) sample injection and holding at 10\% B for 5 min, (ii) linear gradient from $10 \%$ to $90 \%$ B over 15 minutes, (iii) holding at $90 \%$ B for 5 minutes, (iv) isocratic step to $10 \%$ B and holding for 5 minutes prior to the next sample injection. Mass spectrometry was performed on the eluent using electrospray ionization (ESI) in positive ion mode with a scanned $\mathrm{m} / \mathrm{z}$ range from $160-2000$.

\section{Red blood cell lysis}

The hemolytic activity of LL-37, WLBU-2 and CSA-13 (0$200 \mu \mathrm{g} / \mathrm{ml}$ ), against human red blood cells (RBC) was tested using erythrocytes suspended in PBS. RBC prepared from fresh blood (Hematocrit 5\%) were incubated for 1 $\mathrm{h}$ at $37^{\circ} \mathrm{C}$ after addition of test molecules. Relative hemoglobin concentration in supernatants after centrifugation at $2000 \times \mathrm{g}$ was monitored by measuring the absorbance at $540 \mathrm{~nm} .100 \%$ hemolysis was taken from samples in which $2 \%$ Triton X-100 was added.

\section{Cell culture}

Human gastric adenocarcinoma cells (ATCC; CRL-1739) were maintained in DMEM (BioWhittaker) culture supplemented with $10 \%$ heat-inactivated fetal bovine serum (Hyclone) at $37^{\circ} \mathrm{C}$ and $5 \% \mathrm{CO}_{2}$. For LDH release assay and microscope evaluation cells were plated in 24 well plates and grown to confluence. In all experiments, the medium was changed to serum-free media $\sim 12 \mathrm{~h}$ prior to cell treatment with LL-37, WLBU2 and CSA-13 (0-200 $\mu \mathrm{g} /$ $\mathrm{ml}$ ) in individual wells, for 1 hour. Cell culture medium was then collected, centrifuged (10 mins, $5000 \mathrm{rpm}, \mathrm{RT}$ ) and subjected to LDH evaluation (LDH-cytotoxicity Assay Kit; BioVision Inc.)

\section{Competing interests}

Dr P. Savage is a paid consultant for Ceragenix Pharmaceuticals, Innate Immune Inc., and WittyCell. None of the research reported in this paper was supported by Ceragenix Pharmaceuticals or by any other corporate entity. Other authors: none to declare.

\section{Authors' contributions}

KL: carried out the H. pylori study, bacteria killing assay, performed the statistical analysis and drafted the manuscript; AN: carried out immunohistochemical studies; DF: carried out mass spectrometry; QW: participated in the $H$. pylori study; $\mathrm{ZN}$ : collection of gastric mucosal and bile samples, participated in the design of the study and drafted the manuscript; PS: carried out CSA-13 synthesis and participated in study design and helped to draft the manuscript; SD: involved in mass spectrometry analysis and helped to draft manuscript; PJ: participated in study design and helped to draft the manuscript; RB: carried out red blood cell lysis and cell culture study, participated in study design and helped to draft the manuscript. All authors read and approved the final manuscript.

\section{Acknowledgements}

This work was supported by NIH grant HL067286 and Medical University of Bialystok grants 3-22458F and 3-I87/4L

\section{References}

I. Peek RM Jr, Blaser MJ: Helicobacter pylori and gastrointestinal tract adenocarcinomas. Nat Rev Cancer 2002, 2(I):28-37.

2. Marshall BJ, Warren JR: Unidentified curved bacilli in the stomach of patients with gastritis and peptic ulceration. Lancet | 984, I(8390): |3| |- |3|5.

3. Nagata $H$, Wada A, Kurazono H, Yahiro K, Shirasaka D, Ikemura T, Aoyama N, Wang AP, Makiyama K, Kohno S, et al.: Application of Bead-ELISA method to detect Helicobacter pylori VacA. Microb Pathog 1999, 26(2): I03-II0.

4. Kountouras J, Zavos C, Chatzopoulos D, Katsinelos P: New aspects of Helicobacter pylori infection involvement in gastric oncogenesis. J Surg Res 2008, I46(I): |49-I58.

5. Giannakis M, Chen SL, Karam SM, Engstrand L, Gordon Jl: Helicobacter pylori evolution during progression from chronic atrophic gastritis to gastric cancer and its impact on gastric stem cells. Proc Natl Acad Sci USA 2008, I 05(I I):4358-4363.

6. Nardone G, Morgner A: Helicobacter pylori and gastric malignancies. Helicobacter 2003, 8(Suppl I):44-52.

7. Fuccio L, Zagari RM, Minardi ME, Bazzoli F: Systematic review: Helicobacter pylori eradication for the prevention of gastric cancer. Aliment Pharmacol Ther 2007, 25(2): I33-I4I.

8. Tatematsu M, Nozaki K, Tsukamoto T: Helicobacter pylori infection and gastric carcinogenesis in animal models. Gastric Cancer 2003, 6(I): I-7.

9. Romero-Gallo J, Harris EJ, Krishna U, Washington MK, Perez-Perez GI, Peek RM: Effect of Helicobacter pylori eradication on gastric carcinogenesis. Lab Invest 2008, 88(3):328-336.

10. Hamanaka Y, Nakashima M, Wada A, Ito M, Kurazono H, Hojo H, Nakahara Y, Kohno S, Hirayama T, Sekine I: Expression of human beta-defensin 2 (hBD-2) in Helicobacter pylori induced gastritis: antibacterial effect of hBD-2 against Helicobacter pylori. Gut 200I, 49(4):48I-487.

II. Hase K, Murakami M, limura M, Cole SP, Horibe Y, Ohtake T, Obonyo M, Gallo RL, Eckmann L, Kagnoff MF: Expression of LL-37 by human gastric epithelial cells as a potential host defense mechanism against Helicobacter pylori. Gastroenterology 2003, I25(6): 1613-1625.

12. Kawakubo M, Ito Y, Okimura Y, Kobayashi M, Sakura K, Kasama S, Fukuda MN, Fukuda M, Katsuyama T, Nakayama J: Natural antibiotic function of a human gastric mucin against Helicobacter pylori infection. Science 2004, 305(5686): I003-1006.

13. Sorensen OE, Follin P, Johnsen AH, Calafat J, Tjabringa GS, Hiemstra PS, Borregaard N: Human cathelicidin, hCAP-18, is processed to the antimicrobial peptide LL-37 by extracellular cleavage with proteinase 3. Blood 2001, 97( I 2):395 I-3959.

14. Devine DA: Antimicrobial peptides in defence of the oral and respiratory tracts. Mol Immunol 2003, 40(7):43 I-443.

15. Nell MJ, Tjabringa GS, Wafelman AR, Verrijk R, Hiemstra PS, Drijfhout JW, Grote Jj: Development of novel LL-37 derived antimicrobial peptides with LPS and LTA neutralizing and antimicrobial activities for therapeutic application. Peptides 2006, 27(4):649-660.

16. Elssner A, Duncan M, Gavrilin M, Wewers MD: A novel P2X7 receptor activator, the human cathelicidin-derived peptide LL37, induces IL-I beta processing and release. I Immunol 2004, I 72(8):4987-4994. 
17. Jenssen $\mathrm{H}$, Hamill $\mathrm{P}$, Hancock RE: Peptide antimicrobial agents. Clin Microbiol Rev 2006, 19(3):49I-5II.

18. Bucki R, Levental I, Janmey PA: Antibacterial peptides-a bright future or a false hope. Anti-Infective Agents in Medicinal Chemistry 2007, 6: $175-184$

19. Deslouches B, Islam K, Craigo JK, Paranjape SM, Montelaro RC Mietzner TA: Activity of the de novo engineered antimicrobial peptide WLBU2 against Pseudomonas aeruginosa in human serum and whole blood: implications for systemic applications. Antimicrob Agents Chemother 2005, 49(8):3208-32I6.

20. Lai XZ, Feng Y, Pollard J, Chin JN, Rybak MJ, Bucki R, Epand RF, Epand RM, Savage PB: Ceragenins: Cholic Acid-Based Mimics of Antimicrobial Peptides. Acc Chem Res 2008, 4 I ( I0):4936-495 I.

21. Chin JN, Jones RN, Sader HS, Savage PB, Rybak MJ: Potential synergy activity of the novel ceragenin, CSA-13, against clinical isolates of Pseudomonas aeruginosa, including multidrugresistant P. aeruginosa. J Antimicrob Chemother 2008, 6I(2):365-370.

22. Chin JN, Rybak MJ, Cheung CM, Savage PB: Antimicrobial activities of ceragenins against clinical isolates of resistant Staphylococcus aureus. Antimicrob Agents Chemother 2007, 5 I(4): I268-I 273.

23. Felgentreff $K$, Beisswenger C, Griese M, Gulder T, Bringmann G, Bals $\mathrm{R}$ : The antimicrobial peptide cathelicidin interacts with airway mucus. Peptides 2006, 27( ( 2):3100-3106.

24. Bucki R, Namiot DB, Namiot Z, Savage PB, Janmey PA: Salivary mucins inhibit antibacterial activity of the cathelicidinderived LL-37 peptide but not the cationic steroid CSA-13. J Antimicrob Chemother 2008, 62(2):329-335.

25. Santini D, Pasquinelli G, Mazzoleni G, Gelli MC, Preda P, Taffurelli M, Marrano D, Martinelli G: Lysozyme localization in normal and diseased human gastric and colonic mucosa. A correlative histochemical, immunohistochemical and immunoelectron microscopic investigation. Apmis 1992, I00(7):575-585.

26. Hase K, Eckmann L, Leopard JD, Varki N, Kagnoff MF: Cell differentiation is a key determinant of cathelicidin LL-37/human cationic antimicrobial protein 18 expression by human colon epithelium. Infect Immun 2002, 70(2):953-963.

27. Egan $\mathrm{BJ}, \mathrm{O}^{\prime}$ Connor $\mathrm{HJ}, \mathrm{O}^{\prime}$ Morain CA: What is new in the management of Helicobacter pylori? Ir J Med Sci 2008, I77(3): |85- I88.

28. Selgrad M, Malfertheiner P: New strategies for Helicobacter pylori eradication. Curr Opin Pharmacol 2008, 8(5):593-597.

29. Vakil N: Helicobacter pylori treatment: is sequential or quadruple therapy the answer? Rev Gastroenterol Disord 2008, 8(2):77-82.

30. Matteo MJ, Granados G, Olmos M, Wonaga A, Catalano M: Helicobacter pylori amoxicillin heteroresistance due to point mutations in PBP-IA in isogenic isolates. J Antimicrob Chemother 2008, 6 I(3):474-477.

31. Graham DY, Shiotani A: New concepts of resistance in the treatment of Helicobacter pylori infections. Nat Clin Pract Gastroenterol Hepatol 2008, 5(6):32I-33I.

32. Yang YH, Wu WK, Tai EK, Wong HP, Lam EK, So WH, Shin VY, Cho $\mathrm{CH}$ : The cationic host defense peptide rCRAMP promotes gastric ulcer healing in rats. J Pharmacol Exp Ther 2006, 3 I 8(2):547-554.

33. George LL, Borody TJ, Andrews P, Devine M, Moore-Jones D, Walton $M$, Brandl S: Cure of duodenal ulcer after eradication of Helicobacter pylori. Med J Aust 1990, I53(3): 145- 449.

34. Ding B, Guan Q, Walsh JP, Boswell JS, Winter TW, Winter ES, Boyd SS, Li C, Savage PB: Correlation of the antibacterial activities of cationic peptide antibiotics and cationic steroid antibiotics. J Med Chem 2002, 45(3):663-669.

35. Bucki R, Pastore J], Randhawa P, Vegners R, Weiner DJ, Janmey PA: Antibacterial activities of rhodamine B-conjugated gelsolinderived peptides compared to those of the antimicrobial peptides cathelicidin LL37, magainin II, and melittin. Antimicrob Agents Chemother 2004, 48(5): $1526-1533$.

36. Sheehan VM, Sleator RD, Hill C, Fitzgerald GF: Improving gastric transit, gastrointestinal persistence and therapeutic efficacy of the probiotic strain Bifidobacterium breve UCC2003. Microbiology 2007, I53(Pt I0):3563-357I.

37. Gamble BM, Gallagher PA, Shoemaker JA, Parks AN, Freeman DM, Schwegel CA, Creed JT: An investigation of the chemical stability of arsenosugars in basic environments using IC-ICP-MS and IC-ESI-MS/MS. Analyst 2003, I 28(I2):|458-|46|.
Publish with Biomed Central and every scientist can read your work free of charge

"BioMed Central will be the most significant development for disseminating the results of biomedical research in our lifetime. "

Sir Paul Nurse, Cancer Research UK

Your research papers will be:

- available free of charge to the entire biomedical community

- peer reviewed and published immediately upon acceptance

- cited in PubMed and archived on PubMed Central

- yours - you keep the copyright 